\title{
Love for the divine or divine love
}

\author{
Mohammad Ali Hosseini \\ Department of Social Sciences, Payame Noor University, P.O. Box 19395-3697, Tehran, Iran \\ Email: m_hosseini2004@yahoo.com
}

\begin{abstract}
There is no doubt that likes and dislikes develop under the influence of love and hatred. As a person loves, he has a feeling of pleasure and happiness and when he hates, he feels pain, suffocation and anguish. May be, because of this, some great thinkers and Philosophers thought that the aim of good morality was happiness, means a happy life and achievements of this was possible only in love and affectionate life. The highest point of this life was life of love. The secret of attachment of value to this term "Love" should be searched in this fact. But what is more important than the origin of love is the position of beloved. The degree of happy8ness of a person is related to the degree of his love. The status of his love should be assessed by the glory and rank of his beloved. The durability and longevity of the love is connected with the rise and fall of glory of the beloved. The main question is with whose glory and greatness one should put his soul and head at stake so that eternal and durable love is achieved resulting into eternal pleasure and happiness.
\end{abstract}

Keywords: Love, God, Human, Pleasure, Obligation, Beauty.

\section{Introduction}

One of the signs of worship and certainty is love to God, since if human does not acquire knowledge cannot be in love. When a human knows the real beloved and finds that He is the only who deserves worship, then s/he worships Him and reaches from unity in essence to unity in worship. This is since knowledge creates an enthusiasm to God and an interest in following His commands. It also brings obedience and thralldom, as God says in Fater verse 10: Pure words rise to Him, and right action rises it. A believer as a result of continuation in obedience is so absorbed in God's love that the fire of love for God is ablaze in him and from unity in worship reaches unity in love, and becomes of the persons who are referred to in Bagharah chapter verse 165 when God says: those who believed have the highest love to God. God's love to human beings starts when He knows human worthy of carrying His trust and has made him responsible for the trust.

In the holy Quran, God has frequently referred to human beings with love using different features and attributes and has clearly attributed His love to him. In Imran Family (Aal e Emran) verse 76 God says: God loves the righteous. In addition, in verse 136, He says: God loves the benefactors.

\section{Love of Human beings for god}

\subsection{God is the sole and only object to be loved}

Things and human beings are loved by him in accordance to degree of their love for him.

Reasons of birth of love: The Philosophers of Morality believe that love and its high ranks rise because of the following.

1. Longevity and high ranks of Man: Man loves his existence on this basis and desires this to continue. Whatever helps this process, is near and dear to him ant would hate to see it vanishing. [1]

2. Pleasure: Pleasure, both material and spiritual generates love. Human being love an object which is a source of pleasure. 
Material Pleasure - such as Mam's liking for food items, drinks and other things which satisfy his natural instincts. This type of love is attained easily an vanishes easily. Such love for its lower rank is easy to attain and lose and is low ranking love. [2]

Spiritual Pleasure - like ones love for a selfless soldier and his courage and bravery, to an athlete for his devotion to his art, to an honest and pious person for his honesty, to prayers for god - for pious love and devotion in prayers and supplications.

These categories of pleasure generate unparalleled love which can't be described in words. Those who get a drop of this, are the happiest. These pleasures are durable and have long life. The seekers of permanent pleasure and happiness, give up world by and mortal pleasure in favor of this.

3. Obligation: Man is subordinate to noble deeds and obligations and loves those who do good to him. Those who harm him, heart his feelings and man naturally does not have good feeling for him. So noble and good deeds generate love. [3]

4. Beauty, inner and outer: Understanding, beauty and charm produces love. Man likes beauty whether temporal or spiritual. This has a natural and internal source and is related to a person and his individual self.

5. Internal and Spiritual Contact - At times man loves another being, but not for his beauty, or his power and position, but only for his spiritual and inner qualities and liking for these characteristics.

6. Love and social Contact: Social contact amongst people and social co-existence generates relations, love and affection which has its roots in human nature. It is rightly held that the word "ENSAN" is derived from "ONS" (Meaning love) and not from "NESIYAN" (Meaning forgetfulness). [4]

7. Similarities in outwardly qualities - Similarities in obvious qualities also causes love, like liking of children for children and old people for old people, co-professionalisms for each other fall in this category.

8. Relation of Reasoning: The product reasoning is reason and hence is interrelated. It is a part of reason its eff. Reasoning is the origin of its own outcome. Hence they have a love-link between them. [5]

Notwithstanding with the theory that all these above described factors lead to generation of love and irrespective of their independence, all real causes of love in real form exist in god and anything away from that eternal existence is void of reality and truth. Each existence is a part of his existence and away and independent from him has no existence of its own. Each existence is from him and returns to him. It is a part of source of happiness to god and is obliged to him. Each obligation speaks of his beauty 8 and attributes. No doubt, beauty and perfection is only in his existence. There is no doubt that spiritual beauty is real beauty for wise people who possess real vision. The body and soul of human being has an invisible contact with his creator. Perhaps the Holy verse

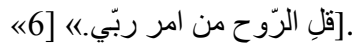

"Say that soul is because of decree of God". Refers to this relationship. Relationship between man and God needs no explanation, and is crystal clear.

The two factors, i.e. social contacts and obvious similarities in qualities play very weak and superfluous role in generating love and secondly it is not proper to relate this with God, it is rather impossible. He has no partner in qualities or otherwise. Causes of love, all in all exist in his existence and there is no partner in love or many other sphere with god. [7].

\subsection{Signs of love of God}

The eternal and true values have always been facing problems at the hands of false pretenders and claimants. These claims and on real ideal are at times so complex that the reality of matter does not dawn even at these people i.e. the claimants, what to say of kids who have no idea about the love of Al-mighty god, but count themselves amongst the lover of god. The signs of such love are the touch stone for knowing the truth. The most visible sign according to eminent religious leaders, is Islamic morality:

1. Love of Death: The real friend desires to see his beloved. Though death is not the only way to see the glory of God, but it is definitely one way to achieve this goal. If one loves something, he loves all ways to reach it.

The Holy Quran Says in this regards,

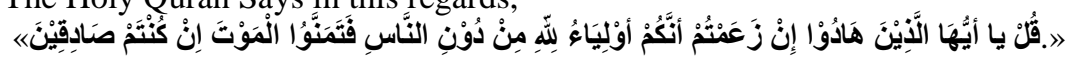

"Oh those who have become Jew, say, if you are friends of god and not of others, if you are telling the truth, pray for Death". [8]. 
As the love for god has ranks and stages, good or bad about death also has ranks, unwelcome attitude towards death is repugnant to love of god if its source is love for worldly wealth, power, ranks, family, etc. but if desire to live long is to prepare for meeting with god it is not repugnant to the spirit of love for god. [9].

2. Priority to will of God: A real friend of god gives priority to the will of god over his own desires, even prefers separation over meeting, if this is the will of god. Love for god entails of his orders and efforts to achieve his concent is its pre requisite.

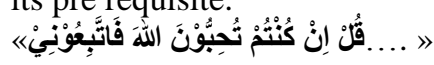

"Say, "If you love god, follow me so that god loves you and pardons your sins, and god is a king forgiver" [10].

3. Non-Negligence in remembering god - Remembering the beloved and all that is related to him, is always a source of pleasure to the lover. Lovers of god always remember him and talk about him. They live in his memory and enjoy reciting his revelation and recite his supplications in seclusion and loneliness, as god said to Moses:

"Oh Son of Emran, he who thinks loves me, is telling lies, when might approaches, closes his eyes from worshipping me, is it not so that each lover loves to be alone with his beloved".[11].

4. Sorrow and Happiness for god: Friends of god never become sad, except for things which distance them from beloved. They are not happy except for things which make them close to the beloved. They are happy with obedience

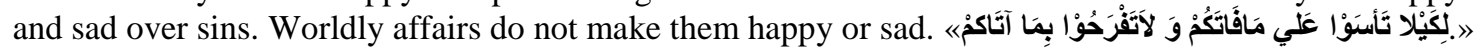

"Do not become sad over what has gone from your hands and not rejoice over what has been given to you. [12].

5. Friendship with friends of god and hostility will his enemies "Prophet Muhammad (P.B.U.H.) is apostle of god and those who are with him, are harsh to infidels and to each other". [13].

6. Fear amidst love and hope: The friends of god while they are overwhelmed with his glory and beauty, as a result of greatness of his being are scared and fearful also. As the realization of his beauty over whelms you, understanding of his greatness makes you \fearful. But this fear is not against love for him. The fear is due to distance, this fear and hope are complimentary to each other in dedication and prayer of god. Some have said: obedience to god only with love and without fear is because of excess in hope and this is dangerous for man. Obedience only due to fear is the result of horror and absence of hope which again is dangerous. Obedience combined with fear and hope leads to $\operatorname{god}[14]$.

7. Concealing love of god and giving up this claim: Love is one of the secrets of beloved, at times things are said in this regard which are not liked and are against facts and hence insulting to the beloved. The greatest and most dedicated lovers and friends of god have at time confessed their failure in love of god. Angels also have no claims of their success as their prayer is not enough to make them such a claim. The real love demands that one considers his love as worthless and insufficient.

\subsection{Symptom of love of God}

Love for god has many signs and outcome and overtakes human personality in multi-dimensional way. Some of its aspects are described below:

1. Love for god: when heart of man is filled with divine love is happy and glory of god unfolds itself upon him, tidings are given to the hearts which are known as "urns", one important sign of this is that one prefers to be remembering god in isolation rather than spending time with other in human social gatherings. Such a person even when he is in gathering is actually alone and is in communion with his friend. His body is with others while heart is with god. [15] Hadrat Amir-ol-Mameneim (A.S. has said about such persons knowledge has shed light of reality on them and they have understood spirit of truth and have reached what is difficult for others to receive. They have become used to what unwise people are unable to. They are in this world but their souls are at the height, they are the vicegerent of god on earth and invite people to his faith and belief. [16].

2. Ecstasy in love for god: Those who want to observe the beauty of god, when wait to see the glory and get to know that they are unable to do so, the desire to do so increases, this state is called, "Maqam-e-Shauq" (the state of desire), while "UNS" rises from sight of it. Desire is the result of inclination. [17].

3. Satisfaction over gods will: It means giving up the habit of objection on what god has given and destined, whether by words or by action. Satisfaction is pre requisite of love. Whatever is given by beloved should he source of satisfaction for the lover. The state of satisfaction is turning point in life and makes hardships and difficulties easy. One 
does not care them for these problems; life and death are equal for him. Nothing is harsh to him as he considers all these from beloved. He is always happy and sees everything with satisfaction. In this way he will always be away from sorrow and grief. The Holy Quran has repeated referred to it, while introducing party of god, Quran says:

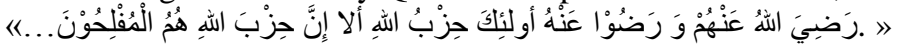

God is happy with them and they are happy with him. They are the party of god, yes party of god and they are relieved and free. [18].

Emam Sajjad (A.S.) says in this regard the highest point of worship, lowest point of abstinence, highest point of selfrestraint, lowest point of confidence and its highest point, are equal to lowest point of state of satisfaction. ألا إنَّ أوْلَيَاءَ اللهِ

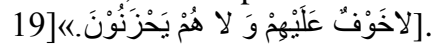

So those who are satisfied are away from all sort of grief and enjoy greatest pleasure. Holy Quran says

Know it that friends of god are neither fearful nor sad. [20].

\subsection{Final result of love of God}

Love of god like all other love, ultimately results in meeting with the beloved. Meeting with god depends on cleanliness of heart and this becomes possible in this world for true lovers. It has always been difficult for people to comprehend this reality and hence many have gone astray.

Hadrat Ali (A.S.) replying to a question of a Kharejite said. The question was "Have you seen your god while praying" and clear and straight reply was, "Shame on you, I am not a person who would worship a god whom I have not seen". The next question was "How have you seen him"? The answer was, "Alas! Shame on you, eyes may8 not but heart has seen him with real faith". [21].

The sight of the divine has real pleasure, pleasure which is beyond description. Those who have enjoyed even a fraction of this pleasure will not compare any happiness with it.

The great devotees of god in their chanting and supplications have exhibited their desire. Great poets too have expressed their desire to see the divine glory and have pointed the pain of separation. For all of them, meeting with Al-mighty is the Zenith of their spiritual achievement. Several treaties covering its all aspects have been written by theologians and philosophers.

\section{God's love for creatures}

The Holy Quran and sayings of members of prophets (P.B.U.H.) family have talked about gods love for some of his devotees. This love has special signs and affect and these are special to some true lovers of god. Anyhow gods general love is for all creatures. As mentioned earlier, Al-Mighty god has in Holy Quran that his love and friendship is declared for Mujahids, noble people, those who do repentance, those who follow abstinence, just, people of patience, pious and those who have full trust in him. [22].

addressing his apart be David, God says "Oh David, tell my creatures on Earth, I am friend to one who loves me I sit with one who sits with me, I am friend to one who is used to loving my name I opt for one who opts for me, obedient to one who is obedient to me. One who truly loves me from the core of his heart, I accept him. I love him more than any creature, one who truly searches for me, he finds me. One, who searches for one other than me, does not find me. So oh earth dwellers, give up wrong and fraud of the world and rush to me, so that I rush to be your friend". [23].

\section{Conclusion}

When human pays attention to God and is positively thinking of god, it makes human be loving God, and as a result his love to God increases. It is because the basis of love which is authenticity between God and human exists in highest degree. That is, it's because God has taught human all His names and attributes and on the other hand He blew his spirit in human, and then there happened closeness between God and human which facilitates human Love to God. More significantly, since the highest desire for human is God and the main origin of man is God, he can Love god more than himself. This love is because of the closeness between god and human.

So friendship between god and his creatures is two dimensional. It is not only man who enjoys supplications of god and lives in desire to see his glory; god also loves to hear affectionate words from his creatures and loves truly to have dialogue with them. 


\section{Acknowledgment}

This research is a grant-based research supported by Payame Noor University, Iran.

\section{References}

[1] M.F.kashani, -Al-Majal Baiza, Qom Publication , Maktabatol Ayatollah Marashi Najafi, Vol. 8, Page 134-135,1984

[2] M.M ,Naraghi , Jame-ol-Saadāt , Qom Publications Maktabatol Ayatollah Marashi Najafi, Vol. 3, Page 136,1984

[3] M.M ,Naraghi , Jame-ol-Saadāt , Qom Publications Maktabatol Ayatollah Marashi Najafi, Vol. 3, Page 136,1984

[4] H.Raghebe Esfahani, Almofradat Fi gharib alghoran, Ketab Publication Office Raghele Esfahaāni - Mofredat-e-Alfaz-e-Qoran- Page 94,1984.

[5] H.Raghebe Esfahani, Almofradat Fi gharib alghoran, Ketab Publication Office Raghele Esfahaāni - Mofredat-e-Alfaz-e-Qoran- Page 139,1984 .

[6] Quran, Sura Arra, Verse 85.

[7] M.F.kashani, -Al-Majal Baiza,Qom Publication, Maktabatol Ayatollah Marashi Najafi - Vol. 8, Page 16-27,1984

[8] Quran ,Sura Juma, Verse 6,

[9] M.M ,Naraghi , Jame-ol-Saadāt , Qom Publications Maktabatol Ayatollah Marashi Najafi, Vol. 3, Page 174-175,1984

[10] Quran, Sura Aal-e-Emaran, Verse 31.

[11] Sadouq, Sheikh Mohammad Ibn Ali Ibn Babewayh, Al Amali, Mohammad Ibn Ali, om, Al Islamia library, Page 438,1983

[12] Quran, Sura Hadeed, Verse 23

[13] Quran ,Sura Fatah, Verse 29

[14] M.F.kashani, -Al-Majal Baiza,Qom Publication, Maktabatol Ayatollah Marashi Najafi, Vol. 8, Page 76-77,1984

[15] M.M ,Naraghi, Jame-ol-Saadāt , Qom Publications Maktabatol Ayatollah Marashi Najafi, Vol. 3, Page 124, 189, 190,1984

[16] S.J,Shahidi,translation Nahj Al Balaqe Explanation, offset company publication, sixth edition, Hekmat 147,2004

[17] M.F.kashani, -Al-Majal Baiza, Qom Publication, Maktabatol Ayatollah Marashi Najafi, Vol. 8, Page 55,1984

[18] Quran, Sura Mojadela, Verse 22, Sura Baiyama, Verse 8.

[19] M. Koleini, Osoul Kafi, Tehran Dar Al Kotob Al Islamia, vol. 2, Page 128, 1983

[20] Quran, Sura Unus, Verse 62.

[21] M. Koleini, Osoul Kafi, Tehran Dar Al Kotob Al Islamia, vol1, Page 149 , 1983,1983

[22] Quran, Baqara, verse 195 and 122. Aale E mran, verse 76, 146, 159; maeda 42 and Toba 108.

[23] S.Tavoos : Mosakeoal faved ,Esfahan, Golbahar publications , p 27, 1995 